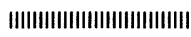

総説

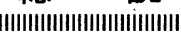

「繊維の50年を振り返る」（その 4)

染色加工技術

短繊維織物加工を中心として(2)

\section{IV. 仕上工程}

\section{1. 綿織物の防しわ加工}

セルロース繊維に属するレーヨン絨維の尿素フォ ルマリン樹脂による樹脂加工は1926年イギリスのッ ータルブロードハーストリー社の技術者により発明 されたが，綿織物に対する加工は，2官能性のエチ レン尿素フォルマリンが発明されて初めて成功した のである. 綿繊維は, レーヨン繊維と同じセルロー スで構成されているが, レーヨンに比べると結晶化 度が高く，組織が密であるため，レーヨンに有効な 三次元構造をとって固化する樹脂では繊維の損傷が ひどくて，うまくいかなかったのである．尿素の官 能基 4 個のうちの 2 個をエチレンによって封鎖した エチレン尿素は官能基が 2 つかないので, 重合し ても固形の樹脂にはならず，セルロース分子の水素 基と結合して架橋結合を作り，結果として織物の防 しわ度を向上するのである，我が国における初期の 綿織物の樹脂加工は，アメリカからの技術導入で行 われ，エバーグレース（1953-54年，バンクロフト 社)，ダンセット（1955年，ダンリバー社）などが加 工された。しかし，エチレン尿素が反応性染料の耐 光堅牢度を阻害することが判明したため，これを克 服するため，エチレン尿素に替ってジヒドロキシエ チレン尿素が使われるようになり，今日に至ってい る.

綿繊維の樹脂加工は，樹脂液に浸した織物をへヴ ィパダーと称する高圧マングルで, 絞った後, 織物 が乾燥して収縮を始める直前まで，ノンタッチドラ イヤーまたはショートループドライヤーで乾燥し, 次いでオーバーフィード機構を備えたピンテンター 上で乾燥した後, 高温キュアラーで樹脂の縮合を行 うことによって実施される。

伊 藤 信 平
森 本 國 宏

ポリエステル／綿混紡織物が普及し，W \& W 性 など，その優れた消費特性があてはやされるように なり始めたとき，100\%綿織物で，同様な W \& W 性 が得られないかという考え方で登場したのが，ウェ ット状態で架橋反応を行って W \& W 性を高めた加 工方法で，ベルファスト加工（1960年，ディアリン グミリケン社）がその代表例であった。これは，綿 織物に通常の樹脂加工を施した後, 苛性ソーダ溶液 に浸した上，エピクロルヒドリンなどのエポキシ化 合物と濡れた状態で反応させ，エポキシ環を開環さ せて，セルロースの間に架橋すると，乾燥状態です 湿潤状態であしわにになりにくくなるという考え力 であった．しかし，これらの加工は，かなり過酷で セルロースを傷めるため，条件のコントロールがシ ビアな上，あらかじめ強度の高い高級綿花を使用す るなどの配慮が必要で，かなりコストが高くつくの が欠点であった．また，この加工によるものは，確 かに優れた $\mathrm{W} \& \mathrm{~W}$ 性を発揮したが，加工後に縫製 を行うため，縫い目のひきつり（パッカリング）が 起こりやすく，また，アイロンでの折り目つけがで きないなどの欠陥があり，この克服が，後に起こっ てくるポストキュア加工や形態保持加工を促したこ とになったのである.

現在，市場に出ている形態保持加工は，次のよう にいくつかに分類できる，すなわち，

（1）織物に樹脂（触媒を含む）をつけ，乾燥だけ したものを縫製してシャッなどに仕立て，プレ スした後キュアする.

（2）無加工のまま，縫製してシャッにしてプレス を行ったあのに，ホルマリンガスチャンバー中 で，反応させ架橋を行う（VP加工）

（3）無加工のままシャッに仕立て，これに樹脂液 を付与してから，プレスし，キュアを行う．樹 脂液付与は, 浸漬・絞液の他, 適量の樹脂液を 
スプレーする方法あある.

いずれの方法む, 織物の状態でなく, シャッなど の最終製品の形態で，樹脂や薬品によって架橋を行 うことにより，縫い目のパッカリングなどを防止す る工夫が行われており，これは，先刻述べた苦い経 験を乗り越えた結果であるといわなければならな い.

\section{2. 綿織物の防縮加工}

サンフォライズ加工（図21,22）が最む有名であ りこてれはフフェルトまたはゴムベルトの伸長と収 縮を利用して，強制的に織物を縦方向に押し込ん で, 爾後の洗濯による縮みを最小にし，洗濯縮み 1\%を保証するもので，クルーエットピーボディ社 の特許である，我が国には，1957年，東洋紡守口工 場にフェルト式のあのが，1958年に東洋紡大阪工場

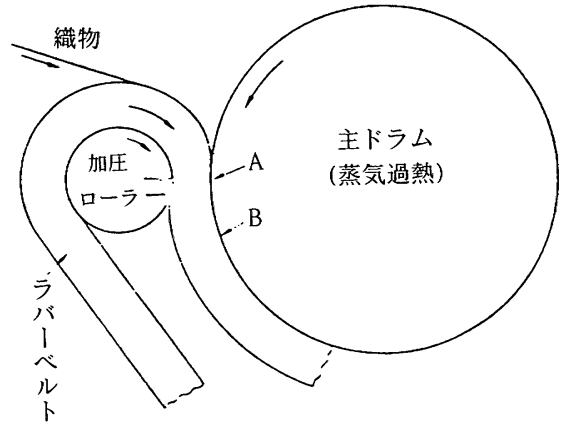

図21 サンフォライズの機構

にラバー式のものが導入されて以来, 急速に普及 し，1960年には全国で24台が設置された。この機械 の国産化は, 1967年に京都機械がクルエットピーボ ディ社と技術提携して生産が開始されている，特許 が期限切れになってから，同種のメカニズムによる

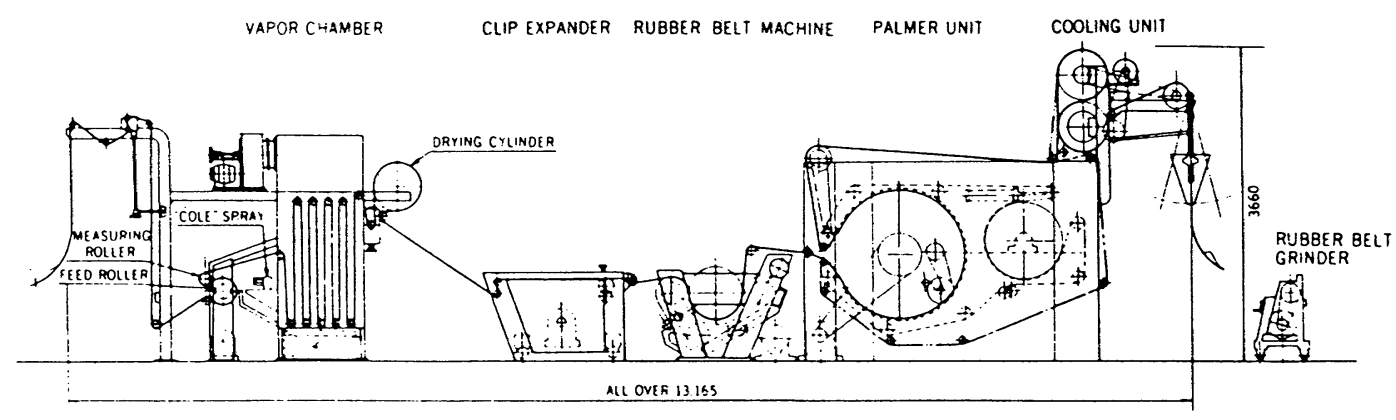

図22 サンフォライズ機

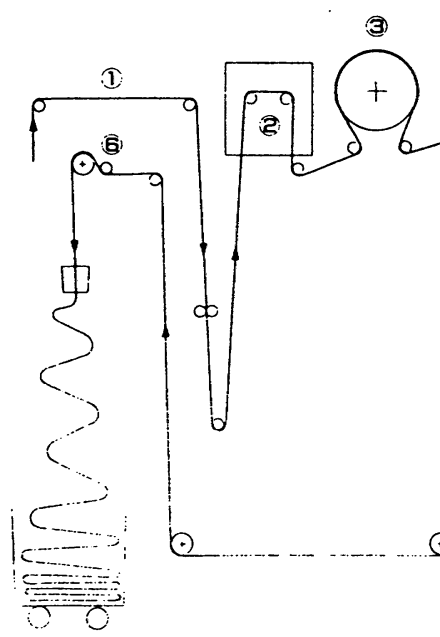

(1)布入口装置

(2)加湿装置

(3)加熱シリンダー

(4)コンパクター
(5)冷却装置

(6)振り落とし装置

(7)ブランケット研磨装置

(8)潤滑液供給装置

図23 カムフィット加工機 
機器がいろいろと作られたが, カムフィット加工機 （上野山機工）（図23）むその1つである.

\section{$\mathrm{V}$. 環境。エネルギー問題}

1945年の第二次世界大戦の終結時点においては, 国内をはじめ欧米においても人々は日々の生活を維 持することにきゅうきゅうとしており，欠乏してい る物をいかに充足するかが, 最大の課題であった.

そのために低コストでの大量生産が最す重要視さ れた時代であった.

国内においても1950年代は，消費財を始めとして いろいろな工業生産が日夜休まず続けられた。すち ろん，国内にはそれらの生産に対する技術的背景が 欠如していたため, 多くは欧米の技術の導入ないし 模倣であり, 製品を作り出すことに無我夢中であっ た.

これらの生産一辺倒から, 製品の安全性や生産過 程から排出される廃棄物に対する見直しの気運が生 まれ出したのが1965年前後からである. 以下にその 代表的な一部を紹介する.

\section{1. ホルマリン規制}

1964年に当時の科学技術庁が「衣料処理剤の諸影 響に関する研究会」を発足させ，当時急速に行われ るようになった化学物質による瀻維加工処理につい ての人体への影響についての調查を開始し, 通産省 はこの調查結果に基づき1971年 7 月に局長通達によ り業界の指導に当たった.

さらに厚生省は1973年 9 月に厚生省令により, 「家庭用品に使用される有害物質に関する規制基準」 の公布を行った。

対象商品の個々では, 通産省の通達よりあ厳格な 法律規制とし，その測定法とともに乳幼児用品につ いては「検出されないこと」その他, 肌に直接触れ る肌着, 寝装品, 靴下等は 75PPM 以下との規制値 が明示された。

その後, この法律には防虫加工剤のデルドリン. BTTB ; 防炎加工の A.P.O. トリホスフェト. ビスホ スフェト; 衛生加工剂のトリフェニルおよびトリブ チルの錫加工物等の濃度および使用を禁ずることが 追加明示された。

以上の通達および法律の制定に伴い, 従来は主に 防縮を目的に大量に使用されていた尿素ホルマリン 系の樹脂剤は, より遊離ホルマリンの少ないグリオ キザール系に転換され, 乳幼児用品にあっては, 非
ホルマリン系の薬剤の開発と実用化が加速された. それと同時に加工工程で生地に多大の張力を掛けな い装置の開発や物理的に収縮を緩和させる装置が導 入された. 特に肌着や乳幼児用途の多いニット加工 企業を中心に海外・国産の装置が導入された.

現在では, 種々の加工薬剤は毒性・発ガン性・皮 膚障害等を充分に考慮に入れた薬剤の使用が必須条 件となっており，一部には天然抽出物を使用して 「健康」をキャッチフレーズにした製品も開発され ている.

なお，最近ドイッを中心としたヨーロッパでの繊 維製品の安全性について「エコテックス」規格を制 定する機運にある.この中のホルマリン含有量の測 定および基準值は日本の厚生省の法律がそのまま準 用されていることは興味深いことである.

\section{2. 排水処理規制}

1950年代後半より産業廃衰物, 特に生産工場より 排出される排水中の污濁物質により種々の分野でそ の障害が発生した，幸い染色整理業にあっては，廃 棄物が人体に大きな影響を及ぼす物質がほとんどな く, アニリン染料やベンジディン系染料のごとく, 作業者に問題のある物質については早くからその使 用が禁止されており，廃棄物の問題は毒性のある物 質よりも, 徐々に環境破壊を起こす, 無機・有機物 質が主体と成っている。

工業排水にかかわる最初の規制は1958年に制定さ れた「工業排水規制法」および「水質保全法」であ ったが，この法律では水質污濁にかかわる企業への 行政の指導・監督の域を出ず，罰則規定がないため に環境浄化には寄与できなかった。

その結果, 1970年に現在の「水質污濁防止法」(以 下水濁法）が制定され, 翌1971年より施行された. この法律は旧法に比へ, 即罰主義で操業停止も含め た罰則規定屯強化し，企業の環境への配慮をより強 固にしたところに大きな変革があった．この法律は 十数回の改訂が行われ, 内容の強化が計られた. 水 濁法の特徴はその運用を大枠において環境庁が規定 し，実際の運用に当たっては個々の自治体の長（都 道府県知事および指定された市長) に細則を委ねて おり, さらに個々の規制値はその地域の流入河川・ 湖沼・海域により市町村条例で上乗せ（規制值の強 化）が盛られている.

有害物質の規制とは若干意味合いを異にするが, 染色企業加の着色排水は, その污濁感から常に近 


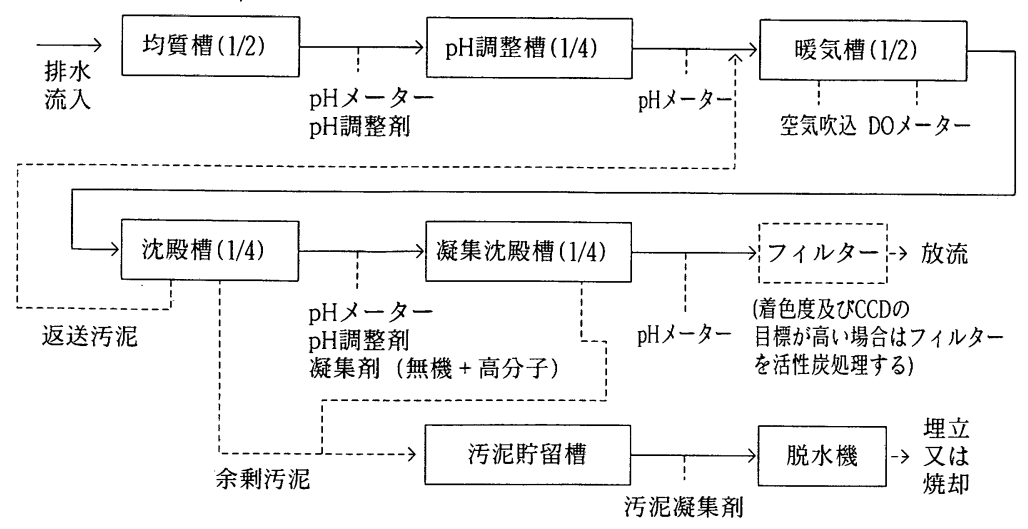

図24 代表的な染色企業の排水処理フロー（ ）内の 数字は日間の水量の割合

隣住民の苦情の原因となっている. 水濁法では着色 度についての明確な規制はないが，この法律では自 治体が独自に決定することす可能である。この主旨 に沿って1994年に和歌山市で着色度に関する条令が 制定され，1995年より実施されている．和歌山市周 辺は国内有数の染色企業の多い地域で, その脱色技 術について過酷な状況下に立ち至っている.

さらに, 最近の行政の動きは, 第四次の総量規制 の動きをにらんで, 今より一層の COD 規制の強化 の方向にあり, 現行主として行われている凝集沈殿 および活性污泥法の組み合わせ（図24）では十分に 対応できなくなる可能性がある，また，長繊維ポリ エステルを加工している企業の減量加工が急速に増 加しており, 従来の設備では COD 負荷が増大し対 応が難しくなっている，その対策の 1 つとして酸析 等の凝集法が採られるが, 発生するオリゴマースラ ッジ量が膨大となり，埋め立て処理場の枯渴と相ま ってその経費が膨大となる.

今後の染色企業の環境対策は, 水質源の枯渴対策 として, 水の使用料の削減と水の再利用技術が求め られるであろう. ゆえに環境の問題は, 単に後処理 技術のみに期待するのではなく, 生産の個々の工程 や仕組みす併せて解決しなければならない時代とな ってきている.

\section{3. 省エネ対策}

繊維染色業は, 全製造業の中であ有数のエネルギ 一多消費型産業である。

このために，1973年からの石油価格の高騰により 経営の根幹が摇さぶられたことは記憶に新しいこと である.
この石油ショックの結果, 染色企業での省エネに 対する取り組みが本格化し, 工程の簡略化と省エネ 設備の導入が1975年以降加速された.

そもそも, 染色産業でのエネルギー多消費は, 多 くの工程が水を媒体とし, それぞれの工程で処理さ れた後に乾燥を行い, 次工程ではまた水を媒体とし た処理を行っている,多いものはこれを 7 回む繰り 返しているケースもある.

一度水に濡らされた生地がすべての工程で乾燥さ れず, 最後で乾燥が行われればエネルギー消費は少 なくて済む. しかし生地に含まれる水分量の制御が 困難なために, 染薬剤を所定量生地に付与するに は, 一度乾燥してから次工程を行う方法が製品の品 質安定には一番簡単な方法である。また，捺染のよ うに絵柄を生地に印捺するには, 乾燥した布地が必 須条件である. 例えば, 連続精練漂白之連続染色の 組み合わせは一見エネルギーの効果的な使用がなさ れているかに見えるが，その間の乾燥回数を考える 之, 回分式 (バッチ式) で精練から染色まで完了さ せるほうが有利ともいえる. 特に昨今の小ロット多 品種の生産を余儀なくされている現状からみると, 連続方式の切り替え時の熱ロスは膨大であり中間乾 燥を必要としない連続方式の開発が必須である.

石油ショック以後, 染色企業で進められた省エネ 対策は(1)現有設備の熱管理による消費エネルギーの 削減, (2)熱効率の良い設備への置き換え, (3)石油以 外のエネルギー源へのシフトであった。

現在, 世界的な製造業の低迷と, 原子力や天然力゙ ス等の石油以外のエネルギー源の開発・普及により 原油価格の低下さらに, 国内においては, 円高もあ って重油価格は石油ショック時の 3 分の 1 になって 
おり, 省エネの企業努力は若干トーンダウンしてい る.しかし, 環境問題とリンクすると化石燃料によ る炭酸ガスの発生は地球温暖化の観点から, 今後引 き続き使用量減少の努力をしなければならない。

現在具体的な方向性は見出だされてはいないが, 炭素税なる制度が，化石燃料の使用量削減の目的で 世界的規模で論議か開始されており，染色産業にお ける省エネルギーは今後あ更なる努力が求められ る.

\section{VI. ファクトリーオートメーション (FA 化)}

20世紀後半の製造業の飛躍的進展を支えたのは， 1940年代初頭にアメリカのベル研究所で開発された 半導体が最大の要因である. 半導体の目的は, 東西 冷戦の中での兵器産業や人工衛星に代表されるロケ ット技術の分野に応用され，その進歩が著しかった ことは，まだ記憶に新しいところである。

特にマイクロプロセッサとセンサーの開発は, 種々の機構の中に組み入れられ，従来の人力による 生産管理を機械に委ねることができるようになり， 製品の均質化と省人化が大きく進歩した. 染色産業 においても，これらの自動化装置の導入は，1980年 以降急速に進み, 特に CCM（コンピュータカラー マッチング) やCCK（コンピュータカラーキッチ ン）は従来の染色工業を技能偏重型から知識・シス テム集約型産業に替えた。この分野は，今日もなお 進化しつつある．さらに，1990年以降は個々の装置 の自動化のみならず，企業や事業所全体にコンピュ 一タのネットワークを構築し, 作業段取り（生産計 画）や受発注業務の情報共有化といったコンピュー 夕による生産システムの構築 (CIM) の普及により, 経営のより一層の合理的生産形態へシフトが試みら
れるようになった。

\section{1.コンピュータカラーマッチング (CCM)}

染色産業での最大の FA 化は，従来人力に全面的 に依存していた調色の分野への適応であった。 $\mathrm{CCM}$ はコンピュータを用いて調色を自動化し，現 在あらゆる業態の染色産業に広く普及している。

(1)各種色材固有の色を分光光度計を使用して，各 波長ごとの反射率を電気信号として取り出し, かつデジタル化しその值を主記憶装置に入力す る.

次いで求められている見本を同様に分光光度 計により，色を数值化し，上記色材のデー夕を 組み合わせ，最適の配合割合を計算する.

同時に色材が用いられる素材の特性値む主記 憶装置に入力し, 出力される色材デー夕に補正 値として計算される。

(2)上記方法で得られた数值を実際に着色し, 求め る色との差異がない場合および差異がある場合 屯，着色品を再度分光光度計に卦けその数值を 記憶させ, 次回の近似の色にデー夕を比較資料 として，本生産での色合わせの精度を上げるよ うに利用する。

(3)上記作業は過去には長年の経験熟練者と膨大な 資料ファイルの検索により作業がなされていた が，未経験の作業者が見本を分光光度計にセッ トするだけの作業で熟練者以上の成果が得られ るようになった。

(4)色材の持っている諸特性（コスト・堅牢性・作 業条件等）を同時に記憶させることにより要求 条件を満たす配合む同時に可能となった.

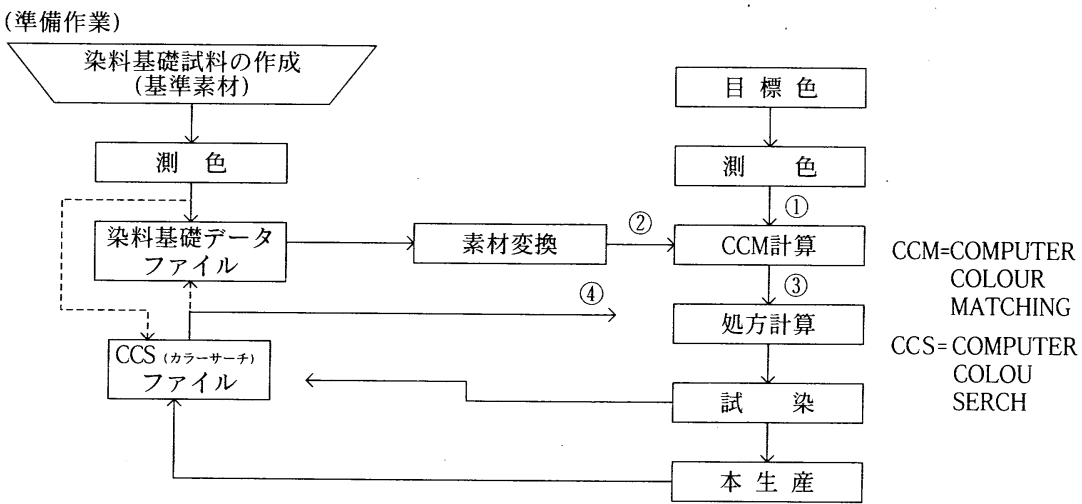


設備の概要図

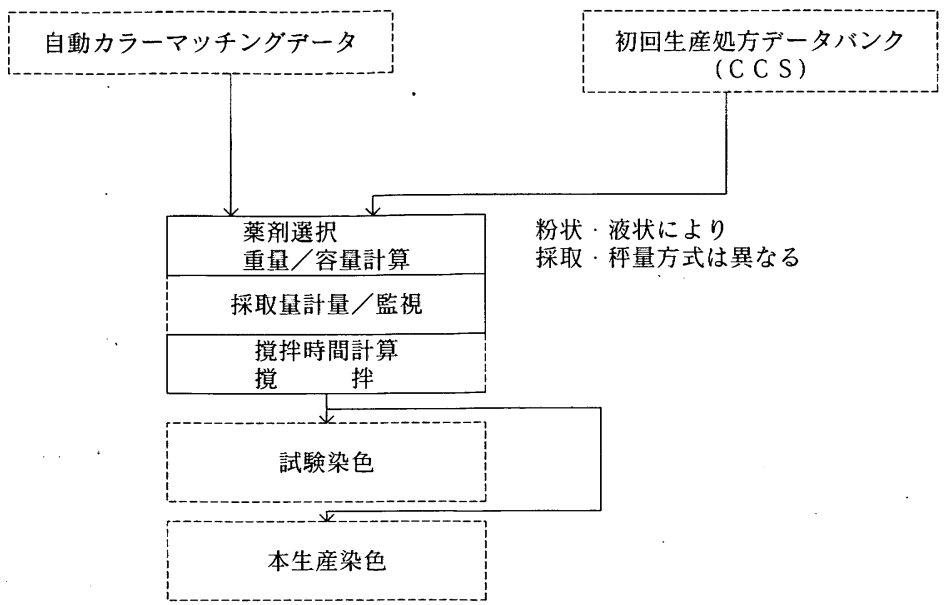

\section{1 コンピュータカラーマッチングの構成}

(1)分光光度計による目標色の自動計測および電子 計算機による比較演算解析

(2)素材に応じた染料の選択（素材別染料基礎デー 夕よりの検索／修正）

(3)素材, 目標色の条件にコスト等の最適条件の処 方計算

(4)過去の実生産色のデータベースよりの近似色の 検索と修正

\section{2 最近の改良点}

(1)演算素子が $16 \mathrm{bit}$ より $32 \mathrm{bit}$ となり, 計算速度 が 4 倍になった。

(2)分光光度計の精度のアップにより，従来 $20 \mathrm{~mm}$ 角の試料が $5 \mathrm{~mm}$ 角の試料で測色可能になっ た。

(3)演算速度の高速化と記憶装置の容量アップによ り，5千色のデー夕容量が 2 万色以上となった.

\section{2.コンピュータカラーキッチン (CCK)}

前項の CCM の進化に併せ，作製された調色処方 箋に基づき，染薬剤の精密科量が必要と成ってき た。これには省人化と人為的なミスの排除, 労㗢環 境の改善等1980年代の染色産業の抱えていた問題点 の解決への大きな課題であった。

染色産業にあっては，種々の色材や薬剤（液体ま たは粉体）を求める量に応じて配合する必要があ る.
開発当初 (1980) は試染用の小型機 (1kg 未満) の みであったが，精度の高い計量ポンプと大容量で正 確な秤量器の開発により，50kg までの調合が可能 になった（1990）。染料も当初は, 液状の染薬剤のみ の装置であり, そのために染料等の低粘度の液状品 の調合で販売が開発されたが, 薬剤の計量容器への 供給方式の考案により高粘度品や粉体品の自動計量 が可能となった．さらに，自動カラーマッチング機 とのプログラムの共通化が進み個々にデータを入力 しなくとも，カラーマッチング装置と連動で作業が 可能となった。

\section{VII. 今後に期待されるもの}

染色加工は，繊維産業のなかにあって，素材と消 費者をつなぐ位置にあり，消費多様化のキィ産業で あるといわれているが，その経営の実態は途上国の 追い上げや，諸物価，特に人件費の高騰などにより 決して楽ではない。しかし，人間が繊維製品を使用 し，その多様化が必要とされる限り，なくなってし まうものではない，一部には，日本のような国は八 イテク産業に専心し, 繊維産業などは途上国に任せ たらよいという議論があるやに聞くが，それは，あ たかも，瑞穂の国の今日の繁栄の基礎となっている 日本人の勤勉さを培ったといわれる農業などの食料 生産は，やめたらよいという議論と同じで，人間の 生活に必要な基礎商品を生産しないというのは，そ の国の文化を放棄するのに等しいと考えるのである がいかがなあのであろうか.とああれ，快適なあの， 美しいものを求める心が失われない限り, 染色加工 は日本においても，実施されなければならないむの 


\section{と考えられる.}

一方, 染色加工は織維産業のなかでは最む多く水 を使い, エネルギー消費む高い産業であるといわれ ている. 特に水に関しては, この産業は上質の水が 大量に得られることなしには存続し得ないと考えら れてきた. しかし, 水の衛星といわれる地球上でむ, そのほとんどは塩水であって, 河川水などの利用可 能な淡水は非常に少なく $(0.0001 \%$ といわれる $)$, 今 後さらに人口の増加が予想されることから, 食料の 確保とともに水の確保は 21 世紀の大問題であるとさ れている. しかも, 染色加工が使用する水は量が多 いのみならず, 洗浄に使用されるため, その使用済 の廃水は, 非常に污染度が高いのもまた事実で, 色, 有機物の除去は種々の手段でできるとしても（もち ろん費用はかかるが), 大量に使用される無機物 (食 塩, 硫酸ソーダなど）の除去は困難を極める.そこ で, そうした無機塩類をなるべく使用しない染色加 工方法が今後追及され, あるいは, 水の使用をゼロ にはできないまでも，できるだけ減らし最終的には クローズドシステムでリサイクルしつつ, 水を使用 する方法をとるというのが今後の染色加工が追及す べき姿であると考えられる. 従って, 従来, 主とし て化学反応に頼って染色加工が行われてきたのであ るが, これからは化学反応だけでなく, 低温プラズ マやスパッタリングのような物理的手段による表面 処理方法が検討されたり，1995年 ITMA（ミラノ） に出展された薬品をできるだけ使用しなくてもすむ 染色方法 2)（ECONTOROL 法：Monfort 社など） や, $\mathrm{CO}_{2}$ の超臨界染色 3）などの革新的な方法の展 開が待たれるのである.

\section{謝 辞}

50 年にわたる染色加工の歴史を少ない紙面で述べ るのは, 容易ではないため, ごく限られた点に絞っ てその歴史を述べた. 原料染め, 糸染めなどについ ては, 触れていないのは, むっぱら紙面の制約のた めであるとご理解戴きたい. 戦後の染色加工技術の 発展の経過については, (財) 機械振興協会・経済研 究所が平成 3 年 2 月に発行した「わが国繊維機械の
技術発展調査研究報告書（III）」（染色仕上げ機械・ 不織布製造機械編）に詳しく述べられているので, 詳細を知られたい方は, 参考されるのがよいと思わ れる. また, すでに入手不可能になっている設備等 の図面についてはここから引用させていただいたこ とを付言し, 深甚なる感謝を申し上げたい.

\section{参考文献}

1) 出野; 染色, 51 号, 13, p46 (1995-3)

2) 井上; 瀻維機械学会誌，49, p84 (1996-1)

3) ibid, 49, p85 (1996-1)

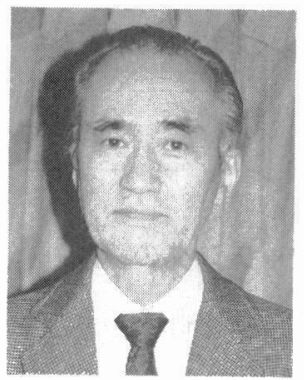

伊藤信平（いとうしんぺい） 昭和 26 年京都大学工学部瀻維 化学科 (現在の高分子化学科) 卒, 日東紡績（株）に勤務し, レーヨンの製造, 染色加工, 熱 可塑コンポジットの開発等に従 事した後, 平成 3 年退社. 現在, 伊藤テクノコンサルタント事務 所経営.（伊藤テクノコンサル タント事務所, テ569 高槻市天 神町 2-16-16, TEL. 0726-816054, FAX. 0726-83-7540)

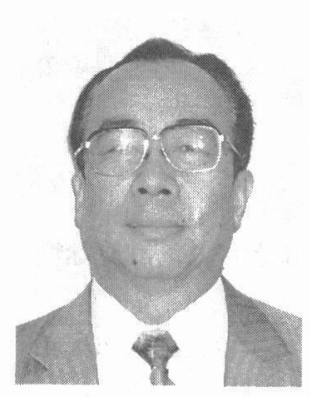

森本國宏（もりあとくにひろ） 昭和 38 年京都工芸織維大学繊 維学部色染工芸科卒, 同年大日 本紡績（株）（現ユニチ力）入 社. 同 43 年マレーシアにて染 色加工の現地指導, その後, 工 二チ力 (株), 大阪染工 (株) を 経て, 同 63 年ナイジェリアに て現地指導, 平成 5 年（社）日 本染色協会に出向, 同 8 年技術 部長兼大阪事務所長に就任. な お, 平成 5 年より ODA の一環 である GAP (Green Aid Plan) 地球環境保全の染色関連専門家 としてASEAN の環境保全の 協力事業に嶊わっている.（日 本染色協会, 干503大阪市北区 東天満 1-6-6, オーセンビル, TEL. 06-358-5515) 